\title{
Determination of parabens in wastewater and sludge in a municipal wastewater treatment plant using microwave- assisted dispersive liquid-liquid microextraction coupled with gas chromatography-mass spectrometry
}

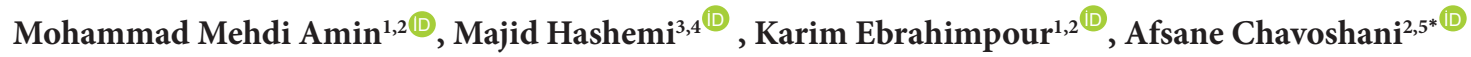 \\ ${ }^{1}$ Environment Research Center, Research Institute for Primordial Prevention of Non-Communicable Disease, Isfahan University of \\ Medical Sciences, Isfahan, Iran \\ ${ }^{2}$ Department of Environmental Health Engineering, School of Health, Isfahan University of Medical Sciences, Isfahan, Iran \\ ${ }^{3}$ Environmental Health Engineering Research Center, Kerman University of Medical Sciences, Kerman, Iran \\ ${ }^{4}$ Department of Environmental Health Engineering, School of Public Health, Kerman University of Medical Sciences, Kerman, Iran \\ ${ }^{5}$ Student Research Committee, Isfahan University of Medical Sciences, Isfahan, Iran
}

\begin{abstract}
Background: Due to the complexities involved in the extraction of micropollutants, the information regarding micropollutants like paraben in wastewater and sludge is scarce. The aim of this study was to adopt a microwave-assisted dispersive liquid-liquid micro-extraction (MADLLME) method for the extraction of parabens in municipal wastewater treatment plant (WWTP).

Methods: A mixed stock solution of methyl-, ethyl-, propyl-, and butyl-parabens with concentration of $10 \mathrm{mg} / \mathrm{mL}$ were prepared in methanol. To validate this method, the limit of detection (LOD), limit of quantification (LOQ), linearity, and $\mathrm{m} / \mathrm{z}$ were measured. To adopt this method in different condition, the effect of $\mathrm{pH}(3,7,9$, and 12), microwave power $(180,300,450$, and $600 \mathrm{~W})$, solvent type (methanol, acetone, methanol/water, acetone/water), and $1 \mathrm{~g}$ folorisil were assessed. After adopting MADLLME method, the paraben fate of this WWTP was evaluated through mass loading and emission.

Results: The optimum performance of MADLLME method was observed at $\mathrm{pH}=7$, microwave power $=450 \mathrm{~W}$, reaction time $=30 \mathrm{~s}$, and methanol as the solvent. The total concentrations of four paraben metabolites in the WWTP ranged between $2505 \mathrm{ng} / \mathrm{L}$ in influent, $1953 \mathrm{ng} / \mathrm{L}$ in effluent, and $8.03 \mathrm{ng} / \mathrm{g}$ at wet weight sludge samples. The total mass loading and emission of four parabens in this WWTP was $0.672 \mathrm{mg} / \mathrm{d} / 1000$ people and $0.186 \mathrm{mg} / \mathrm{d} / 1000$ people, respectively.

Conclusion: MADLLME method seems to be an excellent alternative, as a green extraction technique, for determining various groups of emerging micropollutants in different matrices.

Keywords: Paraben, Environment, Municipal sludge, Dispersive liquid-liquid micro-extraction, Microwave-assisted extraction

Citation: Amin MM, Hashemi M, Ebrahimpour K, Chavoshani A. Determination of parabens in wastewater and sludge in a municipal wastewater treatment plant using microwave-assisted dispersive liquid-liquid microextraction coupled with gas chromatography-mass spectrometry. Environmental Health Engineering and Management Journal 2019; 6(3): 215-224. doi: 10.15171/EHEM.2019.24.
\end{abstract}

Article History:

Received: 17 April 2019 Accepted: 22 June 2019 ePublished: 19 July 2019

\section{Introduction}

Parabens (alkyl esters of p-hydroxybenzoic acid) as favorable ingredients consumed in personal care products (PCPs), pharmaceuticals, nutritional, and industrial products have antifungal and antibacterial properties. Because of their function in endocrine disruption and estrogenic effects, parabens consumption is banned in the EU, the United States, and Canada (1). The maximum permissible level of this substance is $0.4 \%$ in cosmetic products for single ester and $0.8 \%$ for their combination $(2,3)$.

Parabens can be detected in wastewater, water, sediment, soil, human urine, blood, and adipose tissue (2,4-8). Studies conducted in Canada (9), the United Kingdom (10), France (11), and China (12), reported the occurrence of parabens in municipal wastewater. There are studies suggesting that in the conventional WWTPs, these chemicals are not completely removed from the water 
cycle $(8,13-15)$ and this issue remains a challenging problem due to its complex matrices.

Over the last few years, the microwave-assisted extraction (MAE) has been found to be a practical method for extracting target compounds from solid matrices (1620). There are many studies investigated the application of this technique in different compounds extraction from different samples $(17,18,20)$. Due to reducing consumption volume of organic solvents, reducing extraction time and improving recovery yield, the MAE is an appropriate alternative to conventional techniques $(20,21)$. Polar solvents absorb microwave energy, which in turn increase temperature and pressure, and allow rapid transfer of target compounds from the solid matrices into the liquid phase (22).

The solid phase extraction (SPE) and liquid-liquid extraction (LLE) techniques have been introduced to improve the extraction $(23,24)$, which are costly, timeconsuming, and vulnerable to contamination and lack of sensitivity. The objective of the existing analytical techniques is to remove these restrictions and make the analytical procedure simple $(21,23)$. One of the extraction techniques developed within the last decade is the dispersive liquid-liquid microextraction (DLLME). This technique involves the dispersion of fine droplets of extraction solvent in an aqueous sample. Due to the large surface area of the droplets, the separation of analytes into the extraction phase rapidly occurs (21). Here, the advantages of the MAE and DLLME techniques are combined to develop a simple and easy method for extracting methyl paraben (MePB), ethyl paraben (EtPB), propyl paraben (PrPB), and butyl paraben (BuPB) from wastewater and sludge samples through gas chromatography-mass spectrometry (GC-MS).

\section{Materials and Methods}

\section{Samples collection}

Influent and effluent wastewaters and sludge samples were collected from the north WWTP in Isfahan city. The chemical properties of the samples are presented in Table 1. This WWTP serves a population around 1200000 inhabitants with a $220-230 \mathrm{~m}^{3} / \mathrm{d}$ influent flow rate, and consists of a conventional activated sludge (CAS) process. The samples were collected in glass bottles and immediately transferred to the laboratory.

\section{Reagent and chemical}

The MePB, EtPB, PrPB , BuPB, and p-hydroxybenzoic acid (PHA), methanol, acetone and acetonitrile, chlorobenzene, florisil, and N-methyl- $N$-(trimethylsilyl) trifluoroacetamide (MSTFA) with a purity of greater than 98.0\% were purchased from Sigma-Aldrich.

\section{Calibration curve and performance validation}

Ten milligrams of all the paraben standards were dissolved in $1 \mathrm{~mL}$ methanol to make a stock solution at a
Table 1. Chemical properties of samples in the subject WWTP

\begin{tabular}{lccc}
\hline Parameter & Influent & Effluent & Sludge \\
\hline $\mathrm{Q}\left(\mathrm{m}^{3} / \mathrm{d}\right)$ & $220-230$ & 115 & \\
$\operatorname{COD}(\mathrm{mg} / \mathrm{L})$ & 547 & 55 & \\
$\mathrm{BOD}(\mathrm{mg} / \mathrm{L})$ & 240 & 65 & \\
TSS $(\mathrm{mg} / \mathrm{L})$ & 304 & $60-70$ & \\
TKN (mg/L) & 80 & 25 & \\
Dried sludge production (tone/month) & & & 4000 \\
Wet sludge moisture content (\%) & & & 80 \\
\hline
\end{tabular}

concentration of $10 \mathrm{mg} / \mathrm{mL}$. The standard stock solution was sealed and kept at $4^{\circ} \mathrm{C}$ in the lab refrigerator before test. Working solutions with concentration of 10-100 $\mu \mathrm{g} /$ $\mathrm{mL}$ were prepared daily by diluting a more concentrated stock solution with deionized water.

Because the external standards are not correct due to the loss or gain that may occur during preparation of the sample, like in extraction, centrifugation, evaporation, etc., the PHA as an internal standard $(20 \mu \mathrm{g} / \mathrm{mL})$ was spiked to the sample at the beginning of its preparation (25). The PHA was applied to correct the errors due to external calibration curve by plotting the ratio of paraben signal to the internal standard signal. To perform a spikeand-yield relative recovery, a known concentration of parabens and internal standard was added to the sample matrices according to Eq. (1).

$\mathrm{RR} \%=\frac{n_{\text {found }}-n_{\text {real }}}{n_{\text {added }}} \times 100$

where $n_{\text {found }}$ is the concentration of paraben or PHA detected after spiking the sample, $n_{\text {real }}$ is the analytes concentration detected in the real sample, and $n_{\text {added }}$ is the standard concentration spiked to the real sample (25). To validate this method, the limit of detection (LOD) and the limit of quantification (LOQ) expressed as Eqs. (2 and 3), were applied.

$$
\begin{aligned}
& L O Q=\frac{10 s}{S} \\
& L O D=\frac{3 s}{S}
\end{aligned}
$$

where $S$ is the calibration curve slope and $s$ is the regression line SD (26).

The parabens mass in each sample was calculated through Eq. (4).

Paraben mass $=\frac{\mathrm{C} \times \mathrm{V}}{\mathrm{W}}$

where $C$ is the concentration of paraben calculated from the calibration curve equations in Table $2(\mathrm{ng} / \mathrm{mL}), V$ is dilution volume, which was equal to $25 \mathrm{~mL}$, and $W$ is the sludge dry weight, which was equal to $3 \mathrm{~g}(25)$.

Sample preparation and MAE

In this study, sample preparation was designed based 
Table 2. Comparative evaluation of the results of this study with those of other studies

\begin{tabular}{|c|c|c|c|c|c|c|c|c|c|}
\hline $\begin{array}{l}\text { Parabens } \\
\text { Metabolites }\end{array}$ & $\begin{array}{l}\text { Regression } \\
\text { Equation }\end{array}$ & $\begin{array}{l}\text { Linearity } \\
\left(r^{2}\right)\end{array}$ & $\begin{array}{l}\text { LOD } \\
\text { (ng/g) }\end{array}$ & $\begin{array}{l}\text { Retention } \\
\text { Time (min) }\end{array}$ & $\begin{array}{l}\text { LOQ } \\
\text { (ng/g) }\end{array}$ & $\begin{array}{l}\text { RR } \\
(\%)\end{array}$ & $\mathrm{m} / \mathrm{z}$ & Method & Reference \\
\hline \multicolumn{10}{|l|}{ MePB } \\
\hline Sludge & $y=99.26 x-35.54$ & 0.998 & 0.29 & 10 & 0.91 & 82 & 209,224 & MADLLME-GC/FID & This study \\
\hline Sea food & & 0.9999 & 0.06 & 7.61 & 0.2 & & 121,151 & MSPD-GC/MS & (31) \\
\hline Soil & $y=1 x-0.145$ & 0.999 & 0.3 & 7 & 0.9 & & $177,193,209,224$ & MSPD-GC/MS & (23) \\
\hline \multicolumn{10}{|l|}{ EtPB } \\
\hline Sludge & $y=175.48 x-106.54$ & 0.996 & 0.23 & 13.90 & 0.775 & 133 & 223,238 & MADLLME-GC/FID & This study \\
\hline Sea food & & 0.9996 & 0.12 & 7.96 & 0.4 & & 121,137 & MSPD-GC/MS & (31) \\
\hline Soil & $y=0.432 x-0.0453$ & 0.998 & 0.2 & 8.9 & 0.6 & & $\begin{array}{c}193,195,223,237 \\
238,252\end{array}$ & MSPD-GC/MS & (23) \\
\hline \multicolumn{10}{|l|}{ PrPB } \\
\hline Sludge & $y=236.6 x-80.08$ & 0.997 & 0.14 & 14.50 & 0.47 & 91 & 193,200 & MADLLME/GC/FID & This study \\
\hline Sea food & & 0.9996 & 0.12 & 8.61 & 0.4 & & 121,137 & MSPD-GC/MS & (31) \\
\hline Soil & $y=0.3 x-0.03$ & 0.998 & 0.2 & 9.9 & 0.6 & & $\begin{array}{l}195,197,208,210 \\
214,237,241,237\end{array}$ & & (23) \\
\hline \multicolumn{10}{|l|}{ BuPB } \\
\hline Sludge & $y=267.3 x-3.96$ & 0.999 & 0.125 & 15.20 & 0.44 & 100 & 195,210 & MADLLME-GC/FID & This study \\
\hline Sea food & & 0.9994 & 0.3 & & 1 & & 121,137 & MSPD-GC/MS & (31) \\
\hline Soil & $0.415 x-0.0467$ & 0.999 & 0.1 & 10.8 & 0.4 & & 195, 210, 251 & MSPD-GC/MS & (23) \\
\hline
\end{tabular}

on the method of several studies $(21,23,27)$. First, for having better interaction between microwave radiation and sample, the dried sludge granules were crushed and sieved through a $2 \mathrm{~mm}$ sieve to be analyzed chemically, then, $3 \mathrm{~g}$ this powder was diluted with $10 \mathrm{~mL}$ of different solvents and transferred into a glass container and exposed to microwave radiation to be analyzed at different reaction times and microwave powers. Experiments with microwave irradiation were run in a modified domestic microwave oven with a cooling system $(2450 \mathrm{MHz}$, SAMSUNG Co) (Figure 1). This pilot was previously used in the study of Movahedian et al at Isfahan University of Medical Sciences (28).

After cooling, the sample was poured into a $15 \mathrm{~mL}$ Falcon centrifuge and centrifuged at $5000 \mathrm{rpm}$ for $5 \mathrm{~min}$. The supernatant phase was separated, filtered by a syringe filter and diluted in $25 \mathrm{~mL}$ deionized water. $10 \mathrm{~mL}$ of the diluted supernatant was poured into a test tube to be extracted based on DLLME method.

Dispersive liquid-liquid microextraction

Acetone and chlorobenzene were selected as the extraction solvents. According to the DLLME method, first, a mixture of $500 \mu \mathrm{L}$ acetone and $30 \mu \mathrm{L}$ chlorobenzene was injected into $10 \mathrm{~mL}$ of the sample solution to form a cloudy solution, which was next centrifuged at 5000 rpm for 5 minutes (27). The dispersed fine droplets were collected at the bottom of the test tube. A $10 \mu \mathrm{L}$ of the sediment phase was withdrawn by applying a Hamilton microsyringe and injected into $2 \mathrm{~mL}$ microcentrifuge tube. The target sediment was subject to a mild flow of nitrogen until dried. The residue was, first, re-dissolved in $20 \mu \mathrm{L}$ MSTFA, and then, $2 \mu \mathrm{L}$ obtained solution was injected into the GC-MS $(23,27,29)$.

\section{GC/MS instrument characteristics}

The Agilent 7890A GC-System together with MS detector was applied for the separation and quantification of parabens. Agilent 19091S-433MS column with $0.25 \mathrm{~mm}$ thickness, $30.0 \mathrm{~m}$ length, and $0.32 \mathrm{~mm}$ diameter was applied for the separation of parabens. The temperature of injector and detector was $280^{\circ} \mathrm{C}$ and $300^{\circ} \mathrm{C}$, respectively. To begin with, the oven temperature was set at $100^{\circ} \mathrm{C}$ for 4 minutes, followed by a gradual increase up to $240^{\circ} \mathrm{C}$ at a $15^{\circ} \mathrm{C} / \mathrm{min}$ interval. A scan mode was devised to observe

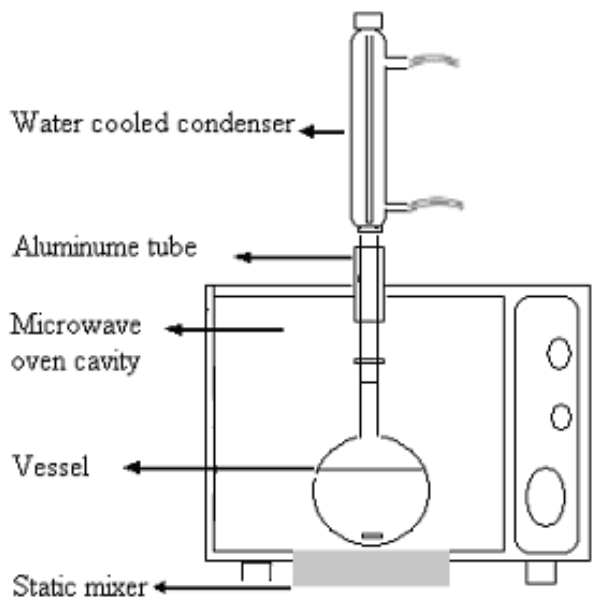

Figure 1. The schematic of the modified microwave system (28). 
the elution time of each analyte, followed by a selective ion monitoring (SIM) mode running for quantitative analysis. Analyses of the results of paraben extraction subject to each variable were repeated twice.

Mass loading, removal, and emission of parabens in the Isfahan north WWTP

The mass loading, removal efficiency, and emission of parabens from the WWTP were calculated through Eqs. (5-7) (30).

Mass load/1000 inhabitation

$=C_{i} \times F_{i} \times\left(\frac{1}{10^{6}}\right) \times\left(\frac{1000}{\text { population }}\right)$

Removal efficiency $(\%)=$

$\frac{\left(C_{i} \times F_{i}\right)-\left[\left(C_{e} \times F_{e}\right)+\left(C_{s} \times T S P\right)\right]}{\left(C_{i} \times F_{i}\right)} \times 100$

Emission $/ 1000$ inhabitants $=$

$\left[\left(C_{e} \times F_{e}\right)+\left(C_{s} \times T S P\right)\right] \times\left(\frac{1}{10^{6}}\right)\left(\frac{1000}{\text { population }}\right)$

where $C_{i}$ is the mean concentration of paraben in wastewater influent $(\mathrm{ng} / \mathrm{L}), C_{e}$ is the mean concentration of paraben in wastewater effluent (ng/L), $F_{i}$ and $F_{e}$ are the daily flow of wastewater influent and effluent $(\mathrm{L} / \mathrm{d})$, respectively, mass load/1000 inhabitants is the mean daily weight of individual parabens introduced into WWTP (mg/d/1000 inhabitants), $C_{s}$ is the mean weight of paraben in sludge (ng/g dry weight), TSP is the total sludge production (g/d. dry weight), population is the number of inhabitants serviced by the WWTP, and emission/1000 inhabitants is the mean daily weight of individual parabens compound discharged through wastewater effluent and sludge (mg/d/1000 inhabitants) (30).
The effects of different variables like the solvent (methanol, acetone, methanol/water, and acetone/water), $\mathrm{pH}(3,7,9$, and 12), florisil as a salt (1 g), microwave power $(180,300$, 450 , and $600 \mathrm{~W})$, and reaction time $(15,30,60$, and $90 \mathrm{~s})$ on paraben extraction were assessed in this study, while the variables subject to the DLLME method remained constant.

Results

Method performance

To validate the paraben extraction from dried sludge through this method, regression equation, linearity, $\mathrm{LOD}, \mathrm{LOQ}$, retention time, recovery, $\mathrm{m} / \mathrm{z}$, and relative recovery (RR\%) were assessed first. As shown in Table 2 , a good linearity was confirmed at $r^{2}>0.99$. The LOD was confirmed in $0.125-0.29 \mathrm{ng} / \mathrm{g}$ range, and LOQ was defined within 0.44 to $0.91 \mathrm{ng} / \mathrm{g}$ range.

The average relative recovery of all parabens in this method was within $82 \%$ to $133 \%$ range. The time required for parabens to pass through chromatography was 18.33 min. The performance results of this study are compared with that of other studies using different methods (Table $2)$. Figure 2 indicates structures and chromatogram of parabens in sludge samples during extraction by MADLLME method.

Effect of reaction time and microwave power on paraben extraction

To improve the MAE, both microwave power and exposure time must be considered. The effect of exposure time on the parabens extraction was examined using a constant microwave irradiation power of $180 \mathrm{~W}$ at reaction times of $15,30,60$, and $90 \mathrm{~s}$. The microwave irradiation of $30 \mathrm{~s}$ led to an increase in the paraben concentration recovery, while a shorter irradiation time (e.g. $15 \mathrm{~s}$ ) led to a decrease in the paraben extraction. Reaction time above $30 \mathrm{~s}$ did not increase the parabens extraction (Figure 3). The

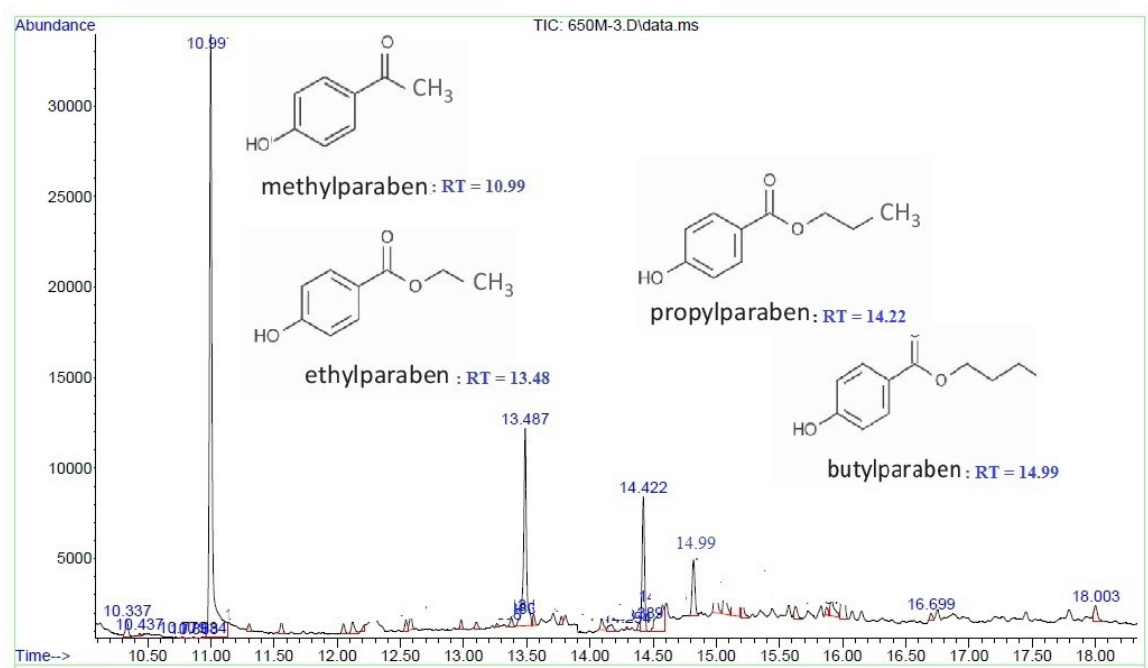

Figure 2. Structures and chromatogram of parabens in the sludge samples during extraction by MADLLME method. 
results obtained at microwave irradiation of $180,300,450$, and $600 \mathrm{~W}$ indicate that microwave irradiation of 450 $\mathrm{W}$ would be sufficient to obtain a good extraction for all parabens (Figure 4).

Effect of extraction solvent on the mean paraben extraction using microwave procedure

In order to assess the solvent type effect on paraben extraction, experiments with constant volume of methanol $(10 \mathrm{~mL})$, acetone $(10 \mathrm{~mL})$, methanol/water $(5: 5$ $\mathrm{v} / \mathrm{v})$, and acetone/water $(5: 5 \mathrm{v} / \mathrm{v})$, were performed. The $\mathrm{MePB}, \mathrm{EtPB}, \mathrm{PrPB}$, and BuPB extractions by methanol were $15,30,11.5$, and $0.9 \mathrm{ng} / \mathrm{g}$, and by acetone are $4.7,17$, 5.2 , and $0.9 \mathrm{ng} / \mathrm{g}$, respectively. The parabens extraction by methanol/water was calculated to be $12.1,25,7$, and 0.9 $\mathrm{ng} / \mathrm{g}$, respectively, and by acetone/water was $4.6,12,5.4$, and $0.9 \mathrm{ng} / \mathrm{g}$, respectively (Figure 5).

Effect of $\mathrm{pH}$ on the mean paraben extraction using microwave procedure

According to the results of experiments, $\mathrm{pH}=7$ was found to be the optimum $\mathrm{pH}$ for paraben extraction using

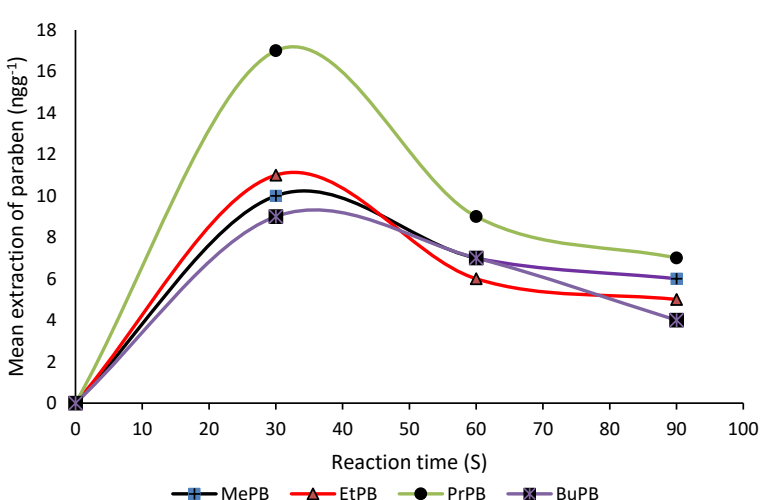

Figure 3. Effect of reaction time on the mean extraction of paraben (sludge weight: $3 \mathrm{~g}$, extraction solvent: $10 \mathrm{~mL}$ methanol, disperser solvents: $500 \mu \mathrm{L}$ acetonitrile and $30 \mu \mathrm{L}$ chlorobenzene, MSTFA: $20 \mu \mathrm{L}$, reaction time: 15,30 , 60 , and $90 \mathrm{~s}$, and microwave power: $180 \mathrm{~W}$ ).

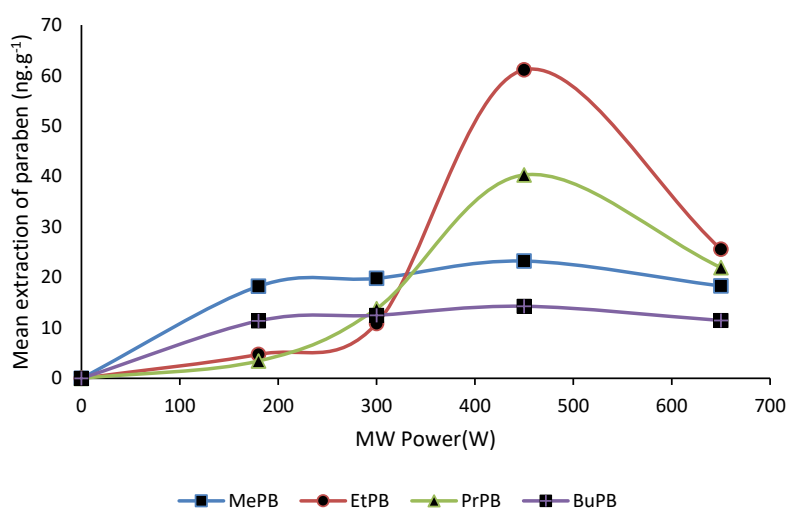

Figure 4. Effect of MW power on the mean extraction of paraben (sludge weight: $3 \mathrm{~g}$, extraction solvent: $10 \mathrm{~mL}$ methanol, disperser solvents: $500 \mu \mathrm{L}$ acetonitrile and $30 \mu \mathrm{L}$ chlorobenzene, MSTFA: $20 \mu \mathrm{L}$, reaction time: $30 \mathrm{~s}$, and microwave power: $180,300,450$, and $600 \mathrm{~W}$ ).
MADLLME method (Figure 6).

Effect of florisil on the paraben extraction using microwave procedure

To assess the florisil effect on the parabens extraction, 1 $\mathrm{g}$ florisil concentration was applied. In comparison with methanol alone, florisil/methanol could improve the mean extraction \pm SD of MP, EP, PP, and BP from influent, wet sludge, and effluent (Figure 7).

Mass loading, removal, and emission of parabens in the subject STP

The MAE method, together with liquid-liquid microextraction, allows rapid detection of parabens in wastewater samples through GC/MS after derivatization. Through this method, it is possible to detect parabens emission into the aqueous environment from STPs. For this purpose, the mass balance method was adopted in this study.

The total of the concentrations of four paraben metabolites ( $\Sigma$ PBs) in the STP was $2505 \mathrm{ng} / \mathrm{L}$ in influent, $1953 \mathrm{ng} / \mathrm{L}$ in

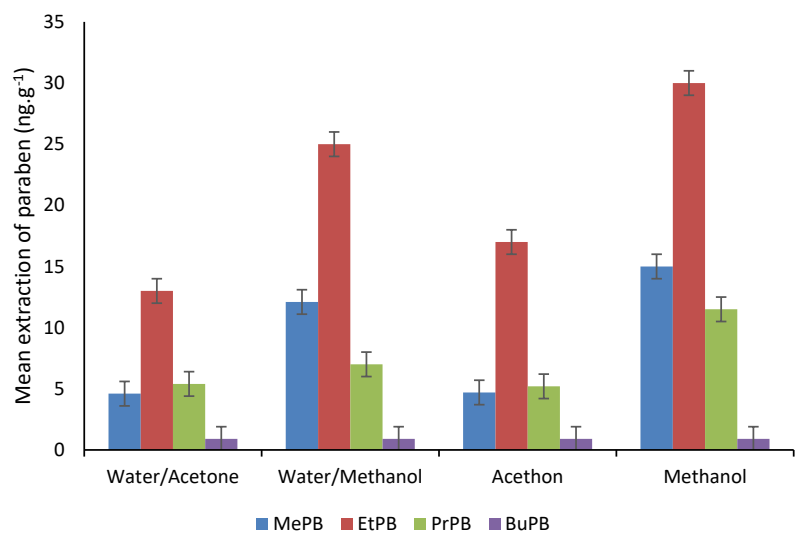

Figure 5. Effect of solvent on the mean extraction $\pm \mathrm{SD}$ of paraben (sludge weight: $3 \mathrm{~g}$, extraction solvents: $10 \mathrm{~mL}$ methanol, $10 \mathrm{~mL}$ acetone, and 10 $\mathrm{mL}$ methanol/water $(5: 5 \mathrm{v} / \mathrm{v}), 10 \mathrm{~mL}$ acetone/water(5:5 v/v), disperser solvents: $500 \mu \mathrm{L}$ acetonitrile and $30 \mu \mathrm{L}$ chlorobenzene, MSTFA: $20 \mu \mathrm{L}$, reaction time: $30 \mathrm{~s}$, and microwave power: $450 \mathrm{~W}$ )

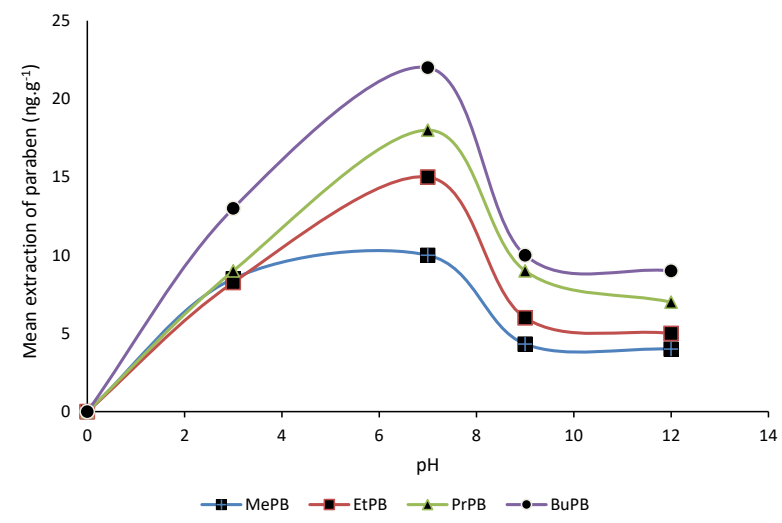

Figure 6. Effect of $\mathrm{pH}$ on the mean extraction of paraben (Sludge weight: $3 \mathrm{~g}$, extraction solvent: $10 \mathrm{~mL}$ methanol, disperser solvents: $500 \mu \mathrm{L}$ acetonitrile and $30 \mu \mathrm{L}$ chlorobenzene, MSTFA: $20 \mu \mathrm{L}$, reaction time: $30 \mathrm{~s}$, microwave power: $450 \mathrm{~W}, \mathrm{pH}: 3,7,9$, and 12). 


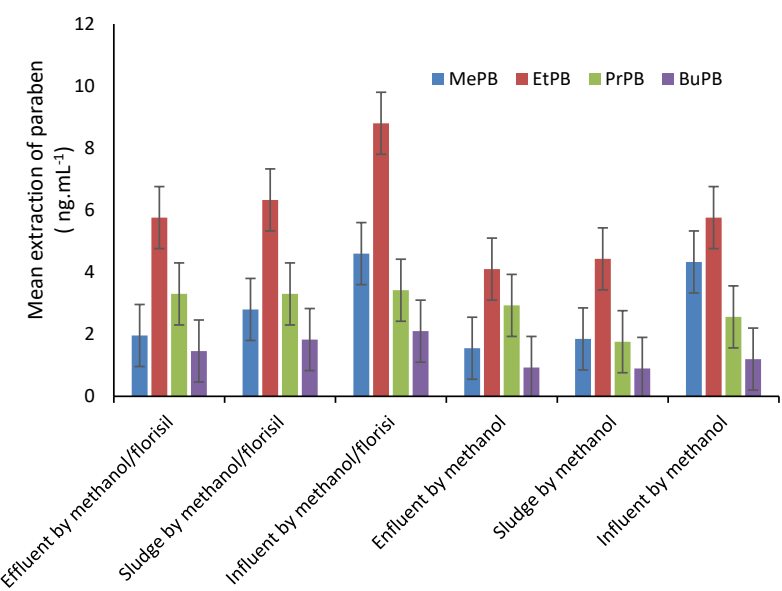

Figure 7. Effect of florisil on the mean extraction \pm SD of paraben (extraction solvent: $10 \mathrm{~mL}$ wet sludge/methanol, $10 \mathrm{~mL}$ effluent/methanol, $10 \mathrm{~mL}$ influent/methanol (5:5 v/v), and $1 \mathrm{~g}$ florisil, disperser solvents: 500 $\mu \mathrm{L}$ acetonitrile and $30 \mu \mathrm{L}$ chlorobenzene, MSTFA: $20 \mu \mathrm{L}$, reaction time: 30 s, and microwave power: $450 \mathrm{~W}$ ).

effluent, and $8.03 \mathrm{ng} / \mathrm{g}$ at wet weight in sludge samples. The total of mass loading and emission of four parabens in this STP was $0.672 \mathrm{mg} / \mathrm{d} / 1000$ people and $0.186 \mathrm{mg} / \mathrm{d} / 1000$ people, respectively. The mean removal efficiencies of $\mathrm{MePB}, \mathrm{EtPB}, \mathrm{PrPB}$, and BuPB were 75, 71, 72, and 62\%, respectively (Table 3 ).

\section{Discussion}

MAE is known as an efficient process in determining PCPs polluted environmental aqueous matrices (34). According to the results, developed MADLLME method enables the extraction of MetPB, EtPB, PrPB, and BuPB form sludge and wastewater samples. This method also satisfies validation criterion through parameters of linearity, RR (\%), LOD, and LOQ. Here, performance results are comparable with those of other studies $(23,31)$. As microwave is highly contributed to the hydrolysis of complex matrices, so determining its optimum conditions is essential (34), which include microwave power, reaction time, solvent, and the use of Florisil as a clean-up agent. In this study, DLLME method condition including volume of the extraction and disperser solvents (chlorobenzene and acetone) and MSTFA was constant.

A review study conducted by Llompart et al showed that MAE together with different methods is able to extract micropollutants from solid matrixes (34). For example, using MAE-SPE method together with GC-MS, Azzouz and Ballesteros extracted 13 enduring disrupting compounds from sludge using $10 \mathrm{~mL}$ methanol/ $\mathrm{H}_{2} \mathrm{O}_{2}$ (3:2 v: v), $500 \mathrm{~W}$ microwave power in 4 minutes reaction time, whereas the amounts of recovery and LOD were 92-98\% and 4.7-5.1 ng/kg, respectively (35). Through the MAE-SPE coupled with GC-MS method, Kumirska et al extracted non-steroidal anti-inflammatory drugs and oestrogenic hormones through $10 \mathrm{~mL}$ water, $400 \mathrm{~W}$ microwave power in 15 minutes reaction time, whereas the amounts of recovery and LOD were $>50 \%$ and 0.3-5.7 $\mathrm{ng} / \mathrm{kg}$, respectively (36).

The molecular interaction using microwave radiation can increase when the microwave power increases. This phenomenon leads to more penetration of solvent into the matrix and better extraction of the solute. Microwave power should not increase the unwanted temperature and pressure (37). In the present study, it was observed that a decrease in the parabens extraction, when microwave power increased, could be due to the possible degradation of parabens (23), therefore, $450 \mathrm{~W}$ microwave power and $30 \mathrm{~s}$ reaction time were selected for the next experiments. The difference of dielectric loss of water (0.123) compared with that of other conventional solvents like methanol (0.659) or acetone (0.054) leads to a difference in the paraben recovery using different solvents or their combination with water. This phenomenon is effective in energy absorption using the proper solvent and increasing its penetration into the matrix (38-40). Solvents with a high dielectric constant and a high dissipation, promote the analytes extraction yield $(41,42)$.

In this study, it was also found that the best extraction mean can be obtained at $\mathrm{pH}$ 7. Any change in the extraction recovery is explained through the change in the parabens' charges. Paraben exists in a protonated form at $\mathrm{pH}$ below 3, where its extraction recovery is low. This low rate is because paraben protonation may greatly weaken the hydrophobic interaction between paraben and other compounds $(43,44)$. At $\mathrm{pH} 4-6.5$, paraben mainly keeps its neutral form, with a slight increase in the extraction recovery due to its net positive charge loses and deprotonation of the hydroxyl group. At $\mathrm{pH}$ 7-9, paraben is in its negative charged form, due to the full deprotonation of hydroxyl group. At $\mathrm{pH}$ above 8, the parabens alkaline hydrolysis process begins, leading to the production of alcohol and hydroxybenzoic acid (45). It is revealed that $\mathrm{pH}$ value together with the organic compounds type are highly contributed in increasing the chemical reaction efficiency using microwave oven $(37,46)$.

Florisil is usually applied to decrease the matrix interference effects on the microwave absorption through solvent and analyte (23). By applying an appropriate florisil/methanol ratio, a good extraction will be obtained (47). Florisil absorbs polar compounds of the matrix and facilitates parabens extraction by methanol (48).

In this study, the mass loading and emission of the $\Sigma \mathrm{PBs}$ were recorded as $0.672 \mathrm{mg} / \mathrm{d} / 1000$ people and 0.186 $\mathrm{mg} / \mathrm{d} / 1000$ people, respectively (Table 3 ).

According to the results of a study conducted in two sewage treatment plants in southern India, concentrations of parent parabens were reported 131-920 ng/L in influent, 16-67 ng/L in effluent, and 104-1090 ng/g dry weight in sludge samples. But the total concentrations of their-metabolites were 4110-34600 ng/L in influent, 2560- 
Table 3. Paraben concentration in the influent, effluent, and sludge together with mass loading, emission, and removal efficiency of parabens in Isfahan WWTP and its comparison with other studies

\begin{tabular}{|c|c|c|c|c|c|c|c|c|}
\hline $\begin{array}{l}\text { Paraben } \\
\text { Metabolites }\end{array}$ & $\begin{array}{l}\text { Influent } \\
\text { (ng/L) }\end{array}$ & $\begin{array}{l}\text { Effluent } \\
\text { (ng/L) }\end{array}$ & $\begin{array}{l}\text { Sludge } \\
\text { (ng/g wet. } \\
\text { weight) }\end{array}$ & $\begin{array}{c}\text { Mass Loading } \\
\text { (mg/d/1000 } \\
\text { people) }\end{array}$ & $\begin{array}{c}\text { Emission } \\
\text { (mg/d/1000 } \\
\text { people) }\end{array}$ & $\begin{array}{c}\text { Removal } \\
\text { Efficiency (\%) }\end{array}$ & Method & References \\
\hline $\begin{array}{l}\text { MePB } \\
\text { Isfahan }\end{array}$ & $\begin{array}{l}* 1219(1000- \\
1300)\end{array}$ & $565(492-654)$ & $1.87(1-375)$ & 0.223 & 0.054 & 75 & $\begin{array}{l}\text { MADLLME } \\
- \text { GC/FID }\end{array}$ & This study \\
\hline A & $\begin{array}{l}36.8(21.7- \\
56.4)\end{array}$ & $\begin{array}{c}0.14(0.14- \\
0.14)\end{array}$ & $41.6(35.3-68.8)$ & 20 & 1.83 & $95.8 \pm 7.78$ & \multirow{2}{*}{$\begin{array}{l}\text { SPE-HPLC- } \\
\text { MS/MS }\end{array}$} & \multirow{2}{*}{ (32) } \\
\hline B & $\begin{array}{l}97.9 \\
(18.3-320)\end{array}$ & $\begin{array}{c}0.14 \\
(0.14-1.73)\end{array}$ & $\begin{array}{c}58.5 \\
(24.3-87.4)\end{array}$ & 113 & 3.71 & $95.2 \pm 5.81$ & & \\
\hline SP & 151 & 28.2 & 16 & \multirow{5}{*}{$\begin{array}{l}\sum \text { parabens } \\
=0.3-36\end{array}$} & \multirow{5}{*}{$0.07-0.9$} & & \multirow{5}{*}{$\begin{array}{c}\text { SPE-HPLC- } \\
\text { MS/MS }\end{array}$} & \multirow{5}{*}{ (33) } \\
\hline $\mathrm{BE}$ & 51 & 4.4 & 31.6 & & & & & \\
\hline MP & 267 & 35.8 & 38.2 & & & & & \\
\hline UP & 138 & 28.9 & 172 & & & & & \\
\hline CO & 209 & 41 & 42 & & & & & \\
\hline $\begin{array}{l}\text { EtPB } \\
\text { Isfahan }\end{array}$ & $\begin{array}{l}1303(1298- \\
2455)\end{array}$ & 703 (245-732) & $3.3(1-2)$ & 0.238 & 0.067 & 71 & $\begin{array}{l}\text { MADLLME } \\
\text { /GC/FID }\end{array}$ & This study \\
\hline A & $4(2.17-8.4)$ & $0.3(0.14-1.47)$ & $2.54(1.74-4.80)$ & 2.05 & 0.35 & $89.8 \pm 10.9$ & & \\
\hline B & $2.75(0.5-66.8)$ & $\begin{array}{c}0.14(0.14- \\
0.29)\end{array}$ & $5.13(1.6-12)$ & 16.5 & 0.32 & $88.5 \pm 7.66$ & $\mathrm{MS} / \mathrm{MS}$ & $(32)$ \\
\hline SP & 40.5 & 8.1 & 5.7 & \multirow{5}{*}{$\begin{array}{l}\sum \text { parabens } \\
=0.5-7.4\end{array}$} & \multirow{5}{*}{$\begin{array}{l}\text { ¿parabens } \\
=0.01-1.2\end{array}$} & & \multirow{5}{*}{$\begin{array}{c}\text { SPE-HPLC- } \\
\text { MS/MS }\end{array}$} & \multirow{5}{*}{ (33) } \\
\hline BE & 11.6 & 1.9 & 6.6 & & & & & \\
\hline MP & 583 & 19.3 & 172 & & & & & \\
\hline UP & 16.2 & 3.9 & 11.2 & & & & & \\
\hline CO & 53 & 7.2 & 13.2 & & & & & \\
\hline $\begin{array}{l}\text { PrPB } \\
\text { Isfahan }\end{array}$ & $761(432-123)$ & 400 (112-467) & $1.95(0.95-4.32)$ & 0.139 & 0.038 & $72 \pm 3.5$ & $\begin{array}{l}\text { MADLLME } \\
\text {-GC/FID }\end{array}$ & This study \\
\hline A & $12.9(9.69-113)$ & $\begin{array}{c}1.16(0.36- \\
4.90)\end{array}$ & $1.38(0.6-2.62)$ & 14.3 & 1.24 & $70.8 \pm 15.7$ & \multirow{2}{*}{$\begin{array}{l}\text { SPE-HPLC- } \\
\text { MS/MS }\end{array}$} & \multirow[b]{2}{*}{ (32) } \\
\hline B & $\begin{array}{l}20.9(8.19- \\
42.3)\end{array}$ & $\begin{array}{c}0.51(0.14- \\
1.10)\end{array}$ & $2.93(0.36-4.64)$ & 17.9 & 0.98 & $91.1 \pm 4.86$ & & \\
\hline SP & 68.1 & 9.8 & 82 & \multirow{5}{*}{$\begin{array}{l}\sum \text { parabens } \\
=2.2-95.3\end{array}$} & \multirow{5}{*}{$\begin{array}{l}\sum \text { parabens } \\
=1.06-1.9\end{array}$} & & \multirow{5}{*}{$\begin{array}{l}\text { SPE-HPLC- } \\
\text { MS/MS }\end{array}$} & \multirow{5}{*}{ (33) } \\
\hline BE & 38.2 & 2.8 & 519 & & & & & \\
\hline MP & 583 & 19.3 & 172 & & & & & \\
\hline UP & 50.2 & 18.4 & 910 & & & & & \\
\hline CO & 55.4 & 8.4 & 404 & & & & & \\
\hline $\begin{array}{l}\text { BuPB } \\
\text { Isfahan }\end{array}$ & $395(245-432)$ & $285(76-306)$ & $0.91(0.5-2.2)$ & 0.072 & 0.027 & 4.2 & $\begin{array}{l}\text { MADLLME } \\
\text {-GC/FID }\end{array}$ & This study \\
\hline A & $\begin{array}{l}5.80(3.15- \\
2.14)\end{array}$ & $\begin{array}{c}0.61(0.36- \\
3.55)\end{array}$ & $0.57(0.36-2.63)$ & 4.30 & 1.24 & $70.8 \pm 15.7$ & \multirow{2}{*}{$\begin{array}{c}\text { SPE-HPLC- } \\
\text { MS/MS }\end{array}$} & \multirow{2}{*}{ (32) } \\
\hline B & $7.25(3.46-112)$ & $\begin{array}{c}0.14(0.14- \\
0.76)\end{array}$ & $11.2(0.55-19)$ & 28.2 & 0.91 & $91.1 \pm 4.86$ & & \\
\hline SP & 10.5 & 2.1 & 0.5 & \multirow{5}{*}{$\begin{array}{c}\sum \text { parabens }= \\
2-0.8\end{array}$} & \multirow{5}{*}{$\begin{array}{c}\sum \text { parabens }= \\
0-0.5\end{array}$} & & \multirow{5}{*}{$\begin{array}{c}\text { SPE-HPLC- } \\
\text { MS/MS }\end{array}$} & \multirow{5}{*}{ (33) } \\
\hline $\mathrm{BE}$ & 8.9 & 2.9 & ND & & & & & \\
\hline MP & 4.4 & 1.4 & 0.7 & & & & & \\
\hline UP & 5.2 & 0.7 & 1 & & & & & \\
\hline CO & 4.1 & ND & ND & & & & & \\
\hline
\end{tabular}

$3800 \mathrm{ng} / \mathrm{L}$ in effluent, and 1220-35900 ng/g dry weight in sludge samples. The average removal efficiencies of parent parabens and their metabolites ranged from $80 \%$ to $100 \%$ and from $28 \%$ to $76 \%$, respectively (30).

In two WWTPs in New York, the median concentrations of the total parabens and paraben-metabolites were 73.1158 and 5460-10000 ng/L in influents, and 1.96-5.57 and 2060-2550 ng/L in the final effluents. The removal efficiencies for parabens (89.6-99.9\%) were higher than those for their metabolites (25.9-90.6\%). The mass loadings of parabens and their metabolites were 46.3 and $6210 \mathrm{mg} / \mathrm{d} / 1000$ people for $\mathrm{WWTP}_{\mathrm{A}}$, and 176 and 63,100 $\mathrm{mg} / \mathrm{d}^{-1} / 1000$ people for $\mathrm{WWTP}_{\mathrm{B}}$, respectively. The average daily environmental emission of parabens and their metabolites was 4.85-6.16 and 1270-2050 mg/d/1000 people, respectively (32). 
In another study performed in Tehran, MePB and EtPB concentrations in the influent and effluent of $\mathrm{WWTP}_{\mathrm{A}}$ were 740 and $277.7 \mathrm{ng} / \mathrm{L}$ and 179.2 and $45.8 \mathrm{ng} / \mathrm{L}$, respectively. Also, $\mathrm{MePB}$ and EtPB concentrations in the influent and effluent of $\mathrm{WWTP}_{\mathrm{B}}$, were 835.2 and 295.2 $\mathrm{ng} / \mathrm{L}$ and 122.8 and $29.7 \mathrm{ng} / \mathrm{L}$, respectively. In these $\mathrm{WWTP}_{\mathrm{s}}$, the removal efficiency was $83-91 \%$ (49), which is higher than that obtained in the present study (Table 3). Also, Gasperi et al evaluated the pollutant mass loads per population equivalent (PE) of parabens, triclosan (TCS), and triclocarban (TCC), where the median mass loading ranged 176 to $3040 \mu \mathrm{g} / \mathrm{PE} / \mathrm{d}$ for parabens and 26 to 762 $\mu \mathrm{g} / \mathrm{PE} / \mathrm{d}$ for the TCS and TCC, respectively (11).

\section{Conclusion}

According to the results, the optimum condition for this method is achieved at $\mathrm{pH}=7$, reaction time $=30 \mathrm{~s}$, microwave power $=450 \mathrm{~W}$, and methanol as solvent. The performance of this proposed method for determination of parabens in the real wastewater and sludge samples reveals good practical results. Overall, MAE coupled with DLLME method seems to be an excellent alternative, as a green extraction technique, for determination of various groups of emerging micropollutants in different matrixes.

\section{Acknowledgements}

Authors would like to gratitude the Vice-Chancellor of Isfahan University of Medical Sciences for its financial support and the proposal approval (code: 95209).

\section{Ethical issues}

This study does not contain any studies with human participants or animals. The authors certify that all the data collected during the study are presented in the manuscript, and no data from the study has been or will be published elsewhere separately.

\section{Competing interests}

The author declare that they have no competing interests.

\section{Authors' contributions}

All authors were involved in data collection, analysis, and interpretation. All authors critically reviewed, refined, and approved the manuscript.

\section{References}

1. Jamal A, Rastkari N, Dehghaniathar R, Aghaei M, Nodehi $\mathrm{RN}$, Nasseri S, et al. Prenatal exposure to parabens and anthropometric birth outcomes: a systematic review. Environ Res 2019; 173: 419-31. doi: 10.1016/j. envres.2019.02.044.

2. Błędzka D, Gromadzińska J, Wąsowicz W. Parabens. From environmental studies to human health. Environ Int 2014; 67: 27-42. doi: 10.1016/j.envint.2014.02.007.

3. Kolatorova L, Vitku J, Hampl R, Adamcova K, Skodova T, Simkova M, et al. Exposure to bisphenols and parabens during pregnancy and relations to steroid changes. Environ
Res 2018; 163: 115-22. doi: 10.1016/j.envres.2018.01.031.

4. Brausch JM, Rand GM. A review of personal care products in the aquatic environment: environmental concentrations and toxicity. Chemosphere 2011; 82(11): 1518-32. doi: 10.1016/j.chemosphere.2010.11.018.

5. Liao C, Lee S, Moon HB, Yamashita N, Kannan K. Parabens in sediment and sewage sludge from the United States, Japan, and Korea: spatial distribution and temporal trends. Environ Sci Technol 2013; 47(19): 10895-902. doi: 10.1021/ es402574k.

6. Moreta C, Tena MT, Kannan K. Analytical method for the determination and a survey of parabens and their derivatives in pharmaceuticals. Environ Res 2015; 142: 45260. doi: 10.1016/j.envres.2015.07.014.

7. Wang L, Asimakopoulos AG, Kannan K. Accumulation of 19 environmental phenolic and xenobiotic heterocyclic aromatic compounds in human adipose tissue. Environ Int 2015; 78: 45-50. doi: 10.1016/j.envint.2015.02.015.

8. Juliano C, Magrin GA. Cosmetic ingredients as emerging pollutants of environmental and health concern. A mini-review. Cosmetics 2017; 4(2): 11. doi: 10.3390/ cosmetics4020011.

9. Lee HB, Peart TE, Svoboda ML. Determination of endocrine-disrupting phenols, acidic pharmaceuticals, and personal-care products in sewage by solid-phase extraction and gas chromatography-mass spectrometry. J Chromatogr A 2005; 1094(1-2): 122-9. doi: 10.1016/j. chroma.2005.07.070.

10. Kasprzyk-Hordern B, Dinsdale RM, Guwy AJ. The removal of pharmaceuticals, personal care products, endocrine disruptors and illicit drugs during wastewater treatment and its impact on the quality of receiving waters. Water Res 2009; 43(2): 363-80. doi: 10.1016/j.watres.2008.10.047.

11. Gasperi J, Geara D, Lorgeoux C, Bressy A, Zedek S, Rocher $\mathrm{V}$, et al. First assessment of triclosan, triclocarban and paraben mass loads at a very large regional scale: case of Paris conurbation (France). Sci Total Environ 2014; 493: 854-61. doi: 10.1016/j.scitotenv.2014.06.079.

12. Sun Q, Li Y, Li M, Ashfaq M, Lv M, Wang H, et al. PPCPs in Jiulong River estuary (China): spatiotemporal distributions, fate, and their use as chemical markers of wastewater. Chemosphere 2016; 150: 596-604. doi: 10.1016/j.chemosphere.2016.02.036.

13. Ortiz de García SA, Pinto Pinto G, García-Encina PA, Irusta-Mata R. Ecotoxicity and environmental risk assessment of pharmaceuticals and personal care products in aquatic environments and wastewater treatment plants. Ecotoxicology 2014; 23(8): 1517-33. doi: 10.1007/s10646014-1293-8.

14. González-Mariño I, Quintana JB, Rodríguez I, Cela R. Evaluation of the occurrence and biodegradation of parabens and halogenated by-products in wastewater by accurate-mass liquid chromatography-quadrupole-timeof-flight-mass spectrometry (LC-QTOF-MS). Water Res 2011; 45(20): 6770-80. doi: 10.1016/j.watres.2011.10.027.

15. Li W, Shi Y, Gao L, Liu J, Cai Y. Occurrence, fate and risk assessment of parabens and their chlorinated derivatives in an advanced wastewater treatment plant. J Hazard Mater 2015; 300: 29-38. doi: 10.1016/j.jhazmat.2015.06.060.

16. Ramezani H, Hosseini H, Kamankesh M, GhasemzadehMohammadi V, Mohammadi A. Rapid determination of 
nitrosamines in sausage and salami using microwaveassisted extraction and dispersive liquid-liquid microextraction followed by gas chromatography-mass spectrometry. Eur Food Res Technol 2015; 240(2): 441-50. doi: 10.1007/s00217-014-2343-4.

17. Zhong Z, Li G, Luo Z, Zhu B. Microwave-assisted dispersive liquid-liquid microextraction coupling to solidification of floating organic droplet for colorants analysis in selected cosmetics by liquid chromatography. Talanta 2019; 194: 4654. doi: 10.1016/j.talanta.2018.09.105.

18. Deo S, Janghel A, Raut P, Bhosle D, Verma C, Kumar SS, et al. Emerging microwave assisted extraction (MAE) techniques as an innovative green technologies for the effective extraction of the active phytopharmaceuticals. Research Journal of Pharmacy and Technology 2015; 8(5): 655-66. doi: 10.5958/0974-360X.2015.00104.3.

19. Naeeni MH, Yamini Y, Rezaee M, Seidi S. Microwaveassisted extraction combined with dispersive liquid-liquid microextraction as a new approach to determination of chlorophenols in soil and sediments. J Sep Sci 2012; 35(18): 2469-75. doi: 10.1002/jssc.201100978.

20. Sanchez-Prado L, Garcia-Jares C, Dagnac T, Llompart M. Microwave-assisted extraction of emerging pollutants in environmental and biological samples before chromatographic determination. TrAC Trends in Analytical Chemistry 2015; 71: 119-43. doi: 10.1016/j. trac.2015.03.014.

21. Kamankesh M, Mohammadi A, Hosseini H, Modarres Tehrani Z. Rapid determination of polycyclic aromatic hydrocarbons in grilled meat using microwave-assisted extraction and dispersive liquid-liquid microextraction coupled to gas chromatography-mass spectrometry. Meat Sci 2015; 103: 61-7. doi: 10.1016/j.meatsci.2015.01.001.

22. Basheer C, Obbard JP, Lee HK. Persistent organic pollutants in Singapore's coastal marine environment: part II, sediments. Water Air Soil Pollut 2003; 149(1-4): 315-25. doi: 10.1023/a:1025673517831.

23. Pérez RA, Albero B, Miguel E, Sánchez-Brunete C. Determination of parabens and endocrine-disrupting alkylphenols in soil by gas chromatography-mass spectrometry following matrix solid-phase dispersion or in-column microwave-assisted extraction: a comparative study. Anal Bioanal Chem 2012; 402(7): 2347-57. doi: 10.1007/s00216-011-5248-0.

24. Rivera L, Curto MJ, Pais P, Galceran MT, Puignou L. Solidphase extraction for the selective isolation of polycyclic aromatic hydrocarbons, azaarenes and heterocyclic aromatic amines in charcoal-grilled meat. J Chromatogr A 1996; 731(1-2): 85-94. doi: 10.1016/0021-9673(95)01224-9.

25. Yang J, Li Y, Gong W, Wang C, Liu B, Sun C. Simultaneous determination of six parabens in foods by matrix liquid-phase dispersion extraction combined with highperformance liquid chromatography. Food Anal Methods 2014; 7(8): 1693-702. doi: 10.1007/s12161-014-9807-9.

26. Shrivastava A, Gupta VB. Methods for the determination of limit of detection and limit of quantitation of the analytical methods. Chron Young Sci 2011; 2(1): 21-5. doi: 10.4103/2229-5186.79345.

27. Han Y, Jia X, Liu X, Duan T, Chen H. DLLME combined with GC-MS for the determination of methylparaben, ethylparaben, propylparaben and butylparaben in beverage samples. Chromatographia 2010; 72(3-4): 351-5. doi: 10.1365/s10337-010-1646-2.

28. Movahedian H, Seidmohammadi A, Asadi A. Comparison of different advanced oxidation processes degrading p-chlorophenol in aqueous solution. J Environ Health Sci Eng 2009; 6(3): 153-60.

29. Djatmika R, Ding WH. Optimization of silylation for parabens determination by gas chromatography-mass spectrometry. Alchemy 2016; 5(2): 55-62. doi: 10.18860/ al.v5i2.3743.

30. Subedi B, Balakrishna K, Sinha RK, Yamashita N, Balasubramanian VG, Kannan K. Mass loading and removal of pharmaceuticals and personal care products, including psychoactive and illicit drugs and artificial sweeteners, in five sewage treatment plants in India. J Environ Chem Eng 2015;3(Part 4A): 2882-91. doi: 10.1016/j.jece.2015.09.031.

31. Djatmika R, Hsieh CC, Chen JM, Ding WH. Determination of paraben preservatives in seafood using matrix solid-phase dispersion and on-line acetylation gas chromatographymass spectrometry. J Chromatogr B 2016; 1036-1037: 93-9. doi: 10.1016/j.jchromb.2016.10.005.

32. Wang W, Kannan K. Fate of Parabens and Their Metabolites in Two Wastewater Treatment Plants in New York State, United States. Environ Sci Technol 2016; 50(3): 1174-81. doi: 10.1021/acs.est.5b05516.

33. Karthikraj R, Vasu AK, Balakrishna K, Sinha RK, Kannan $\mathrm{K}$. Occurrence and fate of parabens and their metabolites in five sewage treatment plants in India. Sci Total Environ 2017; 593-594: 592-8. doi: 10.1016/j.scitotenv.2017.03.173.

34. Llompart M, Celeiro M, Dagnac T. Microwave-assisted extraction of pharmaceuticals, personal care products and industrial contaminants in the environment. TrAC Trends in Analytical Chemistry 2019; 116: 136-50. doi: 10.1016/j. trac.2019.04.029.

35. Azzouz A, Ballesteros E. Determination of 13 endocrine disrupting chemicals in environmental solid samples using microwave-assisted solvent extraction and continuous solid-phase extraction followed by gas chromatographymass spectrometry. Anal Bioanal Chem 2016; 408(1): 23141. doi: 10.1007/s00216-015-9096-1.

36. Kumirska J, Migowska N, Caban M, Lukaszewicz P, Stepnowski P. Simultaneous determination of non-steroidal anti-inflammatory drugs and oestrogenic hormones in environmental solid samples. Sci Total Environ 2015; 508: 498-505. doi: 10.1016/j.scitotenv.2014.12.020.

37. Asgari G, Seidmohammadi A, Chavoshani A. Pentachlorophenol removal from aqueous solutions by microwave/persulfate and microwave/ $\mathrm{H} 2 \mathrm{O} 2$ : a comparative kinetic study. J Environ Health Sci Eng 2014; 12: 94. doi: 10.1186/2052-336x-12-94.

38. Flórez N, Conde E, Domínguez H. Microwave assisted water extraction of plant compounds. J Chem Technol Biotechnol 2015; 90(4): 590-607. doi: 10.1002/jctb.4519.

39. Leadbeater NE. Microwave Heating as a Tool for Sustainable Chemistry. Boca Raton, Florida: CRC Press; 2010.

40. Leonelli C, Veronesi P, Cravotto G. Fundamentals of microwave extraction. In: Chemat F, Cravotto G. Microwave-Assisted Extraction for Bioactive Compounds. New York: Springer US; 2013. doi: 10.1007/978-1-46144830-3_1.

41. Rezaei S, Rezaei K, Haghighi M, Labbafi M. Solvent 
and solvent to sample ratio as main parameters in the microwave-assisted extraction of polyphenolic compounds from apple pomace. Food Sci Biotechnol 2013; 22(5): 1-6. doi: 10.1007/s10068-013-0212-8.

42. Lidström P, Tierney J, Wathey B, Westman J. Microwave assisted organic synthesis--a review. Tetrahedron 2001; 57(45): 9225-83. doi: 10.1016/S0040-4020(01)00906-1.

43. Yin XB, Guo JM, Wei W. Dual-cloud point extraction and tertiary amine labeling for selective and sensitive capillary electrophoresis-electrochemiluminescent detection of auxins. J Chromatogr A 2010; 1217(8): 1399-406. doi: 10.1016/j.chroma.2009.12.029.

44. Noorashikin MS, Raoov M, Mohamad S, Abas MR. Extraction of parabens from water samples using cloud point extraction with a non-ionic surfactant with $\beta$-cyclodextrin as modifier. J Surfactants Deterg 2014; 17(4): 747-58. doi: 10.1007/s11743-014-1574-5.

45. Angelov T, Vlasenko A, Tashkov W. HPLC determination of pKa of parabens and investigation on their lipophilicity parameters. J Liq Chromatogr Relat Technol 2007; 31(2): 188-97. doi: 10.1080/10826070701738787.

46. Chavoshani A, Amin MM, Asgari G, Seidmohammadi A, Hashemi M. Microwave/Hydrogen Peroxide Processes. In:
Ameta SC, Ameta R, eds. Advanced Oxidation Processes for Waste Water Treatment. Elsevier; 2018. p. 215-55. doi: 10.1016/B978-0-12-810499-6.00008-5.

47. Djatmika R, Ding WH, Sulistyarti H. Determination of parabens by injection-port derivatization coupled with gas-chromatography-mass spectrometry and matrix solid phase dispersion. IOP Conf Ser Mater Sci Eng 2018; 299: 012005. doi: 10.1088/1757-899X/299/1/012005.

48. de Pinho GP, Neves AA, de Queiroz ME, Silvério FO. Optimization of the liquid-liquid extraction method and low temperature purification (LLE-LTP) for pesticide residue analysis in honey samples by gas chromatography. Food Control 2010; 21(10): 1307-11. doi: 10.1016/j. foodcont.2010.03.006.

49. Yegane Badi M, Fallah Jokandan S, Rezaei Nia S, Esrafili A, Farzad Kia M, Gholami M. Monitoring of para-hydroxy benzoic acid esters (antimicrobial and preservative) in Tehran wastewater treatment plants and performance evaluation of various wastewater treatment method in the removal of these compounds. Journal of Environmental Health Engineering 2016; 3(4): 259-69. doi: 10.18869/ acadpub.jehe.3.4.259. [In Persian]. 